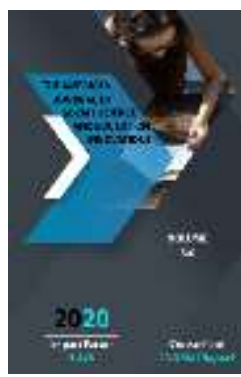

\title{
Substance Laws Of Social Development And Their Role In Knowledge Of The Dialectics Of Democratic Change
}

Javlon Suyundik Ogli Kuchkarov

Independent Researcher, Silk Road International University Of Tourism, Uzbekistan

Journal Website:

http://usajournalshub.c om/index,php/tajssei

\section{Copyright: Original} content from this work may be used under the terms of the creative commons attributes 4.0 licence.

\section{ABSTRACT}

In this article, the substantial laws of social development and their role in understanding the dialectic of democratic change, Cultural Being, The socio-cultural aspects of man are highlighted. The article also discusses the existence and development of society, the substantial basis of the dialectic of national idea and democratic change - the four components of cultural existence - material culture, man and his units, political and legal cultures and spiritual cultures as a whole system. focuses on the analysis of the constituent substantial elements.

\section{KEYWORDS}

Democracy, law, cultural being, society, dialectics, objective reality, laws, national idea and democratic change.

\section{INTRODUCTION}

I.A.Karimov, the founder of the independent Republic of Uzbekistan, said: "I would like to say once again that I am against any revolutions and I am in favor of gradual development. That is, all events must develop on the basis of existing objective laws. Someone may verbally deny these laws. But they must also acknowledge the fact that "there is an objective reality, there are objective laws." If one thinks that it is possible to move from the next stage of social development, say, from a system of, say, slavery, to a system of advanced capitalism without going through the next stage of social 
development, one is seriously mistaken. So think for yourself how a patriarchal and kinship relationship emerges in a democratic state, a leap from feudal society in which patriarchal interests are the decisive factor; Is it possible? " [4:267]. It is clear from these policy ideas that the democratic process is based on the rule of law. The law is connections. But the law is not all of the connections, but part or all of the connections. "Law," said academician J.Tulenov, "is an important, necessary, general, relatively necessary stability of things and events in the objective world, which, under certain conditions, determine the nature and direction of events, requiring a certain definite result relations "[11: 106]. So, the main issue in this paragraph is to define the laws of the national idea and the dialectic of democratic change. Researchers have suggested that this may be the case. Principles are based on laws [14:38]. Principles are expressed in the dialectic of national ideas and democratic change in the form of democratic requirements. That is why the First President of the independent Republic of Uzbekistan I.A.Karimov said: "Democratic processes develop on the basis of their objective laws. They need to be studied and followed.

In the East, democratic processes have their own peculiarities and characteristics that have been formed since ancient times. That fact must be taken into account. " That is, democratic processes in the East will be resolved in an integrated and gradual manner. Attempts to make revolutionary changes in this area will have very important and even tragic consequences.

The need to manage and implement democratic changes and new democratic processes and to protect them must first be understood by society itself " [5: 10-12]. This understanding takes the form of national ideas.

\section{METHODS AND MATERIALS}

In accordance with the dialectical cultural understanding of history, we have seen that the basis of the existence and development of society is the four correlation-functional laws of the existence of society from the interrelationships of the components of cultural existence. There are also substantial laws inherent in cultural existence that form the basis of the development of society. The substantial laws of the evolution of human society are at the same time the systemic laws of democratic processes. Because the basis of a democratic society - all aspects of cultural existence - is a synergistic phenomenon inherent in material, social, political, legal and spiritual cultures, which is required in all spheres of society. Democracy is a kind of harmony. The normal development of all spheres of society depends on harmony. Therefore, it is necessary to supplement the national ideas of democracy with laws on the substantive laws of human society. The correlation-functional and substantial laws of the existence and development of human society are the result of a dialectical cultural understanding of history. These laws were discovered by S. Abdukholiqov [1: 302].

The focus is on the existence and development of society, including the substantial basis of the national idea and the dialectic of democratic change - the four components of cultural existence - material culture, man and his units, political-legal cultures and spiritual cultures as a whole. we focus on the analysis of the substantial elements that make up the system. Substance has essence and substrate. Essential stable relationships within things and events 
[12: 148]. "Substrate" means base in Latin [13: 12-13]. The carriers of the stable connection within things and events are the bases of the same substrates. For comparison: the essence of life is in the metabolism of protein bodies [2: 266]. The substrates of these metabolism are nucleic acids.

Hence, substance is the basis of the first foundation or foundations. If we apply the above ideas to human history, material existence becomes the substance of society. Cultural beings also have their own substrates, the substantial elements that make up the system, which are also the substantial elements that make up the system of the national idea and the dialectic of democratic change.

The system is a legitimate whole [6: 413]. The substantial elements that make up a system of cultural beings, including the national idea and the dialectic of democratic change, are: 1) people; 2) human needs and interests; 3) the realization of these needs and interests, that is, consciousness; 4) creative and transformative activity of people on the basis of perceived needs and interests; 5) results of creative activity of people; 6 ) assimilation of results of creative activity.

Let us take the first of the substantial elements that make up this system - man and his units. Man is the main subject of society, its main link [6: 413].

Man is a solitary and biosocial cultural being. It's a biological, semi-cultural phenomenon. In it, the process of cultivating nature, the upright walk in the process of labor, the law of natural selection is lost, the front legs are captured. Gender and age are biological phenomena. Depending on them, the rights of children, the rights and responsibilities of parents and children. In our country, too, understanding and guaranteeing them, ensuring their harmony is a dialectic of national ideas and democratic change. Race is the result of a geographical environment. Preventing racial discrimination is also a democracy.

Let's take the socio-cultural aspects of a person - profession, social status, nationality, religion, etc. Democratic demands have also been made in relation to these socio-cultural aspects. Thus, man is the main substantial element of all aspects of cultural existence, including the system of national ideas and the dialectic of democratic change. Man and his micro and macro units are the creator, carrier and subject of a whole cultural being, including the dialectic of national ideas and democratic change. The second of the substantial elements that make up this system of cultural existence, including the national idea and the dialectic of democratic change, is the perceived need and interest. It takes on a cultural character only when human needs and interests are understood. Biological and social needs: a set of them are the democratic requirements required in every sphere of social life. The need is the lack of something. The benefit is that the individual and the nation retain their status. On August 31, 1981, we achieved a century-old democratic need and interest - independence. At the international level, we are equal. Hence, need and interest are the motives for the emergence of cultural beings, including democratic regimes.

The third of the substantial elements that make up a system of cultural existence, including the national idea and the dialectic of democratic change, is consciousness, including democratic consciousness. Sh.O.Madayeva showed the laws of mentality related to democratic thinking [7: 261]. The mind is always social in 
nature. Forms of social consciousness and their sections on democracy are shaped by different needs and interests. There are elements of democratic consciousness, whether consciousness is at the level of living thinking or abstract thinking, whether at the level of everyday consciousness or theoretical consciousness, whether at the level of social psychology or social ideology. Because social existence and its components require democratic harmony. It is the task of the human mind to know the needs for the required democratic harmony. Without democratic needs, democratic activity will not take place. Universal and national ideas about democracy are formed in the same substantial element - the theoretical stage of consciousness. The public outcry over the presidential election in Belarus, which began on August 11, 2020, is an example of daily awareness-raising.

Hence, consciousness as a whole is the epistemological basis of its emergence as a substantial component of a cultural being. Similarly, on the basis of a general affirmation, we draw a partial affirmation: our national ideas, consisting of democratic views, serve as the epistemological basis of the democratic reforms taking place in our country.

The fourth substantial element that makes up the system of cultural existence, including the national idea and the dialectic of democratic change, is human creative activity. Social activity is an integral part of a cultural being and a mode of existence in its entirety. Social activity consists of stages of creative and assimilation activities of people. Human creative activity occurs and operates on the basis of an understanding of needs. If creative activity is a substantial element that makes up the fourth system of cultural being, assimilation, including consumption activity, is the sixth substantial element that makes up the system of cultural being. One of the manifestations of social activity is that democratic activity is a way of existence of the national idea and the dialectic of democratic change. Democratic activity also consists of two stages: the creation of democratic ideas and the implementation of democratic ideas.

Cultural existence, including the fifth substantial element that makes up the system of the national idea and the dialectic of democratic change, is the result of creative activity. Cultural being and its components arise because of people's creative activities, including democratic creativity. The results of the creative phase of the activity are the necessary items, food, norms and ideas. The products produced in the first stage of social activity have their own manifestations in each sphere of social life, and they serve as the source and means of the existence of a cultural being. National ideas about democracy also serve as a theoretical source and tool for democratic practice. If one of the results of human creative activity - "... After the field of national ideas loses its integrity, - says B.Sh.Mamarasulov, - this system begins to disintegrate, and in the process of disintegration will form a new structure. and inevitably breaks down into different components "[8:35]. In such situations, national ideas of democracy cannot fully serve as a source of democratic change.

The sixth substantial element of the cultural being, including the national idea and the dialectic of democratic change, which constitutes the system, is the implementation of the results of creative activity. This means that the national ideas of democracy will be implemented, and democratic changes will 
take place. Democratic change also revolves around historical necessity. The implementation of the results of creative activity is also a social activity, its second and main stage. This stage also serves as the mode of existence of the cultural being. Democratic change is also a way of existence of the national idea and the whole dialectic of democratic change.

These six substantial elements that make up the system of cultural existence, including the national idea and the dialectic of democratic change, are genetically intertwined. Since the first substantial element is human beings, the second substantial element is related to them the perceived need and interest, including the need for democracy. These needs form the third substantial element, consciousness. The third substantial element - the formed consciousness, including democratic thinking, and the fourth substantial element - leads to creative activity, including the creation of democratic norms. The results of creative activity are the result of the fourth substantial element as a fifth substantial element of the dialectic of cultural existence, including the national idea and democratic change, and its genetic continuation. Depending on the fifth substantial element of the cultural being, including the national idea and the dialectic of democratic change, arises its sixth substantial element - the implementation of the results. This substantial genetic, continuous process does not end with the implementation of the sixth substantial element - the results of creative activity. Perhaps this process of realization will continue again with the satisfaction of the second substantial element - the perceived need. Perceived need, including the satisfaction of democratic needs, ensures the existence of subjects of cultural existence, including the national idea and the dialectic of democratic change. In these substantial genetic connections there is a specific mechanism of quantitative and qualitative changes. We say this because the first, second, third, and fourth substantial elements that make up a system of cultural beings have a whole set of qualitative characteristics. These are - man and the components of his existence - the perceived need, consciousness and creative activity. In the system of substantial components that make up these four systems, there are mainly quantitative changes. If we say that these four components are the first stage in the formation of a cultural being, then the 5th substantial element - the results of creative activity - has a certain qualitative specificity - integrity. Therefore, the results of creative activity are the second stage in the formation of a cultural being. Substantial element 6 - the implementation of the results of creative activity also has its own qualitative characteristics. Therefore, the implementation of the results of creative activity is the third stage in the formation of a cultural being. The third stage of the formation of a cultural being ensures the existence of the first stage. That is, the substantial element 6 - the implementation of the results of creative activity - the substantial element 2 - must ensure the satisfaction of human needs. On the basis of this normal cultural process emerges the core of society - the law of substantial integrity of the cultural being. This results in the stability of society in a particular historical space and time. And conversely, the existence of democratic order in a system of cultural existence leads to stability. Stability is a basic condition of democracy.

"If we look at history," said Professor M.Is'hakov, doctor of historical sciences, "the 
meaning of the general social movement in the history of mankind will be revealed on the scale of general development." It is the same social movement in human history and its various local and private manifestations around the world. They are united by the generality of the laws of development. For the historian, it is the ability to see commonality in particular and particular in commonality"[3:12]. At the national level, this general substantial process takes place in each sphere and system of social life.

Take, for example, the establishment of a small business. It takes a certain amount of money, raw materials, tools and manpower to form it. From their quantitative concentration, the enterprise rises to the second stage. Now the raw material, the power of the wrist, will be transferred to certain consumer goods. Finished consumer goods have a specific quality that they did not have in the first place. The third stage of the formation of the enterprise is the sale of these consumer goods, including consumption. If the consumer goods are not sold and cannot find specific customers, the company will go bankrupt. If the sales phase can meet the needs of consumers, the needs of the enterprise will be met, and thus the existence and development of the enterprise will be ensured. The occurrence of these processes depends on the existing democratic order within the enterprise, and, conversely, the preservation of the enterprise is a condition for the normal functioning of economic democracy.

\section{RESULTS}

These substantial processes also predominate in the dialectic of national ideology and democratic change. First, the subjects of democracy, second, democratic needs, third, democratic consciousness, fourth, democratic creativity, fifth, the results of democratic creativity - the implementation of democratic norms, procedures and institutions, and sixth, the results of democratic creativity - these are the national idea and are the six substantial elements that make up the system of the dialectic of democratic change. In this system, the first substantial element serves as the subject of the national idea and dialectic of democratic change, the second as the motive, the third as the epistemological basis, the fourth and sixth as the means of existence, and the fifth as the source and means of existence. In this system, too, the first, second, third and fourth substantial elements have their own purpose and qualitative specifics, so the first stage of the dialectic of national idea and democratic change, the fifth substantial element - the results of democratic creativity. the second stage, which has its own specific characteristics, and the implementation of the results of democratic creativity, which is also a third stage, which consists of specific processes. In this system, too, the first stage leads to the second stage, the second stage to the third stage, and the third stage ensures the existence of the first stage if the sixth substantial element - the implementation of democratic creativity - meets and meets the second substantial element - democratic needs. This democratic movement gives rise to the law of the substantial integrity of the national idea and the dialectic of democratic change. This law is the mechanism of the national idea and the dialectic of democratic change. This law serves to ensure the normal development of the country. Again, we turn our attention to the system of universal laws, as outlined by Doctor of Historical Sciences, Professor M. Is'hakov, and move from it to the specifics. The foundation of human history is 
the existence of the second and third substantial laws of cultural existence. The three stages of cultural existence, or the six substantial elements that genetically reproduce each other, continue uninterrupted. The movement does not end with consumption, but with the need for daily creative processes. That is why there is a progressive movement in the cultural being every day and every year. We call this process the law of the substantial progressive circular cycle of cultural being. This is the evolution of human history. This law points to the source of the evolution of human history, including the dialectic of national ideology and democratic change. Because the second substantial element - needs and the sixth substantial element - the assimilation of results consumption is the two poles of cultural existence. Their interdependence is a cultural being, which means the unity and existence of society. Their denial of each other leads to a struggle between the two poles, that is, the movement and development of a cultural being. Conflict between them leads to the transition from one quality to another.

Human needs are constantly evolving based on consumption. This is the direction of cultural existence. So the law of increasing demand is not only an economic law, but also a substantial law of universal consumption. The three substantial laws inherent in a cultural being are the substantial integrity of the cultural being, the substantial progressive circular cycle of the cultural being, and the laws of increasing need are universal laws. As mentioned above, they prioritize and privatize in all areas of social life. In particular, the continuity of the substantial elements and stages of the national idea and the dialectic of democratic change is constantly evolving.
From this continuity arise the substantial progressive circular cycle of the national idea and the dialectic of democratic change, and the laws of increasing democratic needs. If morality (moral democracy) is the lowest level of democracy inherent in all spheres of social life, the highest level is the legitimacy of legal laws and their guarantee by the state power. "When moral and legal norms are violated in the country," said A. Muminov, "from the point of view of legal law, the number of strong, evil people who prefer to use brutal physical force begins to increase" [9:6-7]. The source of this and similar contradictions is the law of the substantially progressive circular cycle of the national idea and the dialectic of democratic change. At the same time, it should be noted that the law of the substantially progressive circular cycle of the national idea and the dialectic of democratic change shows the contradictions that have arisen in this area, and the main way to resolve them is compromise. In particular, the basic democratic requirement in our foreign policy is sovereign equality. Equality is the first requirement of democracy. That is why the President of the Republic of Uzbekistan Sh.M.Mirziyoyev said: "We carry out our activities in the field of foreign policy, first of all, taking into account the interests of our people and our Motherland. The basis of this policy is peace, non-interference in the internal affairs of other states, and the peaceful settlement of conflicts and contradictions only through peaceful, political means "[10].

\section{CONCLUSION}

Hence, there are specific substantial laws of the national idea and the dialectic of democratic change, which are: 
- Firstly, the law of substantial integrity of the national idea and the dialectic of democratic change;

- Secondly, the national idea and democratic change the law of the progressive circular cycle of dialectics;

- And the thirdly, the law of the growth of democratic needs.

It is of great theoretical and practical importance to supplement our knowledge of democracy with ideas about these laws.

\section{REFERENCES}

1. Abdukholiqov S. Freedom of conscience: problems of methodology. - T .: “Fan", 1997. Page 302

2. Engels F. The dialectic of nature. - $T$.: “O'zbekistan", 1983. 266 pages.

3. Is'hakov M. Some comments on the method and methodology of historical research. // "Vodiynoma" socio-historical, scientific and popular magazine. 2016. №1soni.12-p.

4. Karimov I.A. No one can turn us back from the path we have chosen (from answers to the questions of babnot and reporters at a press conference for local and foreign media on the events of May 12-13, 2005 in Andijan). Volume XIII, page 331.//National idea: theoretical sources (chrestomathy). T .: “Academy”, 2007. 267 p.

5. Karimov I.A. Basic principles of political, social and economic prospects of Uzbekistan. - T .: “O’zbekistan”, 1995. P. 1012.

6. Materials of the Republican scientificnational conference devoted to the study of the "Concept of further deepening democratic reforms and development of civil society in our country." (Tashkent, March 16, 2011). - T .: Publishing House of the National University of Uzbekistan, 2011. $413 \mathrm{p}$.

7. Madayeva Sh.O. Features of the formation of democratic thinking in the Uzbek mentality. Doctor of Philosophy. ... Dissertation. - T., 2009. 261bet.

8. Mamarasulov B.Sh. National Ideology and the Ideology of Independence: A Dialectic of Substantive and Institutional Features. T .: “Navruz", 2018. p.35.

9. Muminov A. Uzbekistan: towards an informed society. - T .: "Turon Zaminziyo", 2013. P. 6-7.

10. The rule of law and the interests of the people are the key to the development of the country and the well-being of the people. Speech by the President of the Republic of Uzbekistan Sh. Mirziyoyev at the solemn ceremony dedicated to the 24th anniversary of the adoption of the Constitution of the Republic of Uzbekistan // "Khalk so'zi" newspaper, December 8, 2016.

11. Tulenov J. Theory of dialectics. - $T$.: "O'zbekiston", 2001. p.106.

12. Tulenov J. Theory of dialectics. - $T$.: “O'zbekiston”, 2001. p.148.

13. To'rayev B.O. Being: essence, forms, feature. - $\mathrm{T}$.: Institute of Philosophy and Law, 2011. pp. 12-13.

14. Yaxshilikov J.J. Philosophical and methodological bases of knowledge of the principles of civil law in the years of independence. - T .: MG HTI Publishing House of the Republic of Uzbekistan, 2018. 38 pages

15. Khudoyberdiyevich, D. A., \& Rakhmonqulovich, K. N. (2019). The historical significance of" dastur ulmuluk"("guide to the kings") by khoja 
The American Journal of Social Science and Education Innovations (ISSN - 2689-100x)

Published: November 30, 2020 | Pages: 341-349

Doi: https://doi.org/10.37547/tajssei/Volume02Issue11-58

2020: $5 \cdot 525$

samandar termizi. Journal of Critical

Reviews, 7(6), 2020.

16. Omonov, Q., \& Karimov, N. (2020). Importance of Ancestoral Heritage. The

American Journal of Social Science and

Education Innovations, 2(09), 196-202. 